\title{
Electron and Ligand Transfer Reactions between Cyclometallated Platinum(II) Compounds and Thallium(III) Carboxylates
}

\author{
ANTONIUS F. M. J. VAN DER PLOEG, GERARD VAN KOTEN* and KEES VRIEZE \\ Anorganisch Chemisch Laboratorium, J. H. van't Hoff Instituut, University of Amsterdam, Nieuwe Achtergracht 166, 1018 WV \\ Amsterdam, The Netherlands
}

Received July 14, 1981

Reaction of trans-[(2- $\left.\left.\mathrm{Me}_{2} \mathrm{NCH}_{2} \mathrm{C}_{6} \mathrm{H}_{4}\right)_{2} \mathrm{Pt}^{\mathrm{II}}\right]$ with $\mathrm{Tl}^{\mathrm{III}}\left(\mathrm{O}_{2} \mathrm{CR}\right)_{3}(\mathrm{R}=\mathrm{Me}, \mathrm{i}-\mathrm{Pr})$ gave direct elimination of $\mathrm{Tl}^{\mathrm{I}}\left(\mathrm{O}_{2} \mathrm{CR}\right)$ and formation of the oxidative addition product $\left[\left(2-\mathrm{Me}_{2} \mathrm{NCH}_{2} \mathrm{C}_{6} \mathrm{H}_{4}\right)_{2} \mathrm{Pt}^{\mathrm{rV}}\left(\mathrm{O}_{2} \mathrm{CR}\right)_{2}\right]$, in two isomeric forms. A structure with the carbon ligands in trans positions is proposed for the main isomer, whereas the second isomer has the nitrogen ligands in trans positions. Conversion of the first isomer into the second was induced by addition of free carboxylic acid; evidence for nupture of a Pt-O bond is given and a five-coordinate intermediate proposed. Pt-O bond rupture does not occur for the trans- $N$-isomer.

For $\left[\left\{2,6-\left(\mathrm{Me}_{2} \mathrm{NCH}_{2}\right)_{2} \mathrm{C}_{6} \mathrm{H}_{3}\right\} \mathrm{PtBr}\right]$ with $\mathrm{Tl} / \mathrm{O}_{2}$ $C R)_{3}(R=M e, i-P r)$ two competing reactions have been observed, i.e. cis oxidative addition resulting in formation of cis-O- $\left\{\right.$ \{2,6- $\left.\left(\mathrm{Me}_{2} \mathrm{NCH}_{2}\right)_{2} \mathrm{C}_{6} \mathrm{H}_{3}\right\} \mathrm{Pt} / \mathrm{O}_{2}-$ $\left.\mathrm{CR})_{2} \mathrm{Br}\right]$ with elimination of $\mathrm{Tl}^{\mathrm{I}}\left(\mathrm{O}_{2} \mathrm{CR}\right)$, and exchange of the bromide atom and a carboxylato group between the two metal centres. For $R=M e$ a product has been isolated with stoichiometry $/\{2,6$ $\left.\left.\left(\mathrm{Me}_{2} \mathrm{NCH}_{2}\right)_{2} \mathrm{C}_{6} \mathrm{H}_{3}\right\} \mathrm{Pt}\left(\mathrm{O}_{2} \mathrm{CMe}\right)\right]_{2} \cdot \mathrm{Tl}\left(\mathrm{O}_{2} \mathrm{CMe}\right) \cdot 2 \mathrm{H}_{2} \mathrm{O}$, which is the adduct of some of the products of the above reactions. Adduct formation has been observed as the only reaction for $\left[\left\{2,6-\left(\mathrm{Me}_{2} \mathrm{NCH}_{2}\right)_{2} \mathrm{C}_{6} \mathrm{H}_{3}\right\}\right.$ $\left.\mathrm{Pt}\left(\mathrm{O}_{2} \mathrm{CR}\right)\right]$ and $\mathrm{Tl}\left(\mathrm{O}_{2} \mathrm{CR}\right)_{3}$, resulting in [\{2,6-( $\mathrm{Me}_{2}$ $\left.\left.\left.\mathrm{NCH}_{2}\right)_{2} \mathrm{C}_{6} \mathrm{H}_{3}\right\} \mathrm{Pt}\left(\mathrm{O}_{2} \mathrm{CR}\right) \cdot \mathrm{Tl}\left(\mathrm{O}_{2} \mathrm{CR}\right)_{3}\right]$. The reactions of cis- $\left[\left(2-\mathrm{Me}_{2} \mathrm{NCH}_{2} \mathrm{C}_{6} \mathrm{H}_{4}\right) \mathrm{Pt}\right]$ and cis- $/(2-$ $\left.\left.\left.\mathrm{Me}_{2} \mathrm{NC}_{6} \mathrm{H}_{4} \mathrm{CH}_{2}\right)_{2} \mathrm{Pt}\right)\right]$ with $\mathrm{Tl}^{\mathrm{III}}\left(\mathrm{O}_{2} \mathrm{CR}\right)_{3} \quad(\mathrm{R}=$ $\mathrm{Me}, \mathrm{i}-\mathrm{Pr})$ are less well understood as compared with the corresponding reactions with $\mathrm{Hg}^{\text {II }}$ $\left(\mathrm{O}_{2} \mathrm{CR}\right)_{2}$.

In none of the reactions has evidence for covalent $\mathrm{Pt}-\mathrm{Tl}$ bonded intermediates been obtained. This result has been interpreted with an inner-sphere mechanism operating in electron transfer reactions involving $\mathrm{Tl}^{\mathrm{II}}\left(\mathrm{O}_{2} \mathrm{CR}\right)_{3}$.

\footnotetext{
*Author to whom correspondence should be addressed.
}

\section{Introduction}

In a previous report it has been shown that reactions of mercury(II) carboxylates with organoplatinum(II) compounds in which the organo group contains hard nitrogen donor atoms can result in formation of stable dinuclear $\mathrm{Pt}-\mathrm{Hg}$ complexes [1]. For reactions of mercury(II) carboxylates with other organoplatinum(II) compounds, both transmetallation $[2-4]$ and redox reactions $[4,5]$ have been observed and $\mathrm{Pt}-\mathrm{Hg}$ bonded species have been proposed as possible intermediates [3].

For reactions of thallium(III) carboxylates with organoplatinum(II) compounds there are only a few reports and these indicate reaction patterns similar to those of $\mathrm{Hg}\left(\mathrm{O}_{2} \mathrm{CR}\right)_{2}$. With both mercury and thallium carboxylates transmetallation was observed for organoplatinum compounds containing phosphine ligands [6] (see eqn. 1).

$$
\begin{aligned}
& {\left[\mathrm{Me}_{2} \mathrm{Pt}\left(\mathrm{PPh}_{3}\right)_{2}\right]+\mathrm{M}\left(\mathrm{O}_{2} \mathrm{CR}\right)_{\mathbf{x}} \rightarrow} \\
& {\left[\mathrm{Me}\left(\mathrm{RCO}_{2}\right) \mathrm{Pt}\left(\mathrm{PPh}_{3}\right)_{2}\right]+\mathrm{M}\left(\mathrm{O}_{2} \mathrm{CR}\right)_{\mathbf{x}-1} \mathrm{Me}}
\end{aligned}
$$

whereas the dimeric platinum(II) compound $\left[\mathrm{Me}_{2}-\right.$ $\left.\mathrm{Pt}\left(\mathrm{SEt}_{2}\right)\right]_{2}$ gave elimination of $\mathrm{Hg}^{\mathrm{O}}$ and $\mathrm{Tl}^{\mathrm{I}}\left(\mathrm{O}_{2^{-}}\right.$$\mathrm{CMe}$ ), respectively, and formation of the dinuclear $\mathrm{Pt}^{\mathrm{III}}$ compound $\left.\left[\mathrm{Me}_{2}\left(\mathrm{MeCO}_{2}\right) \mathrm{Pt}\left(\mathrm{SEt}_{2}\right)\right\}_{2}\right]$ [5] (see eqn. 2).<smiles>C[P+]1(C)P[Pb]1(C)C</smiles>
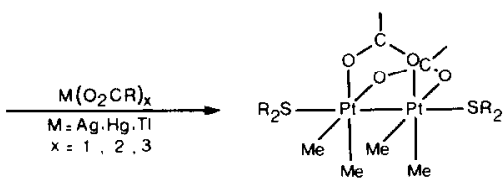

Investigations on other $\mathrm{d}^{8}$-metal complexes in our laboratory showed, however, a large difference between mercury and thallium salts. The syntheses of a series of stable $\mathrm{Rh}-\mathrm{Hg}$ and $\mathrm{Ir}-\mathrm{Hg}$ bonded compounds from mercury(II) carboxylato, formami- 

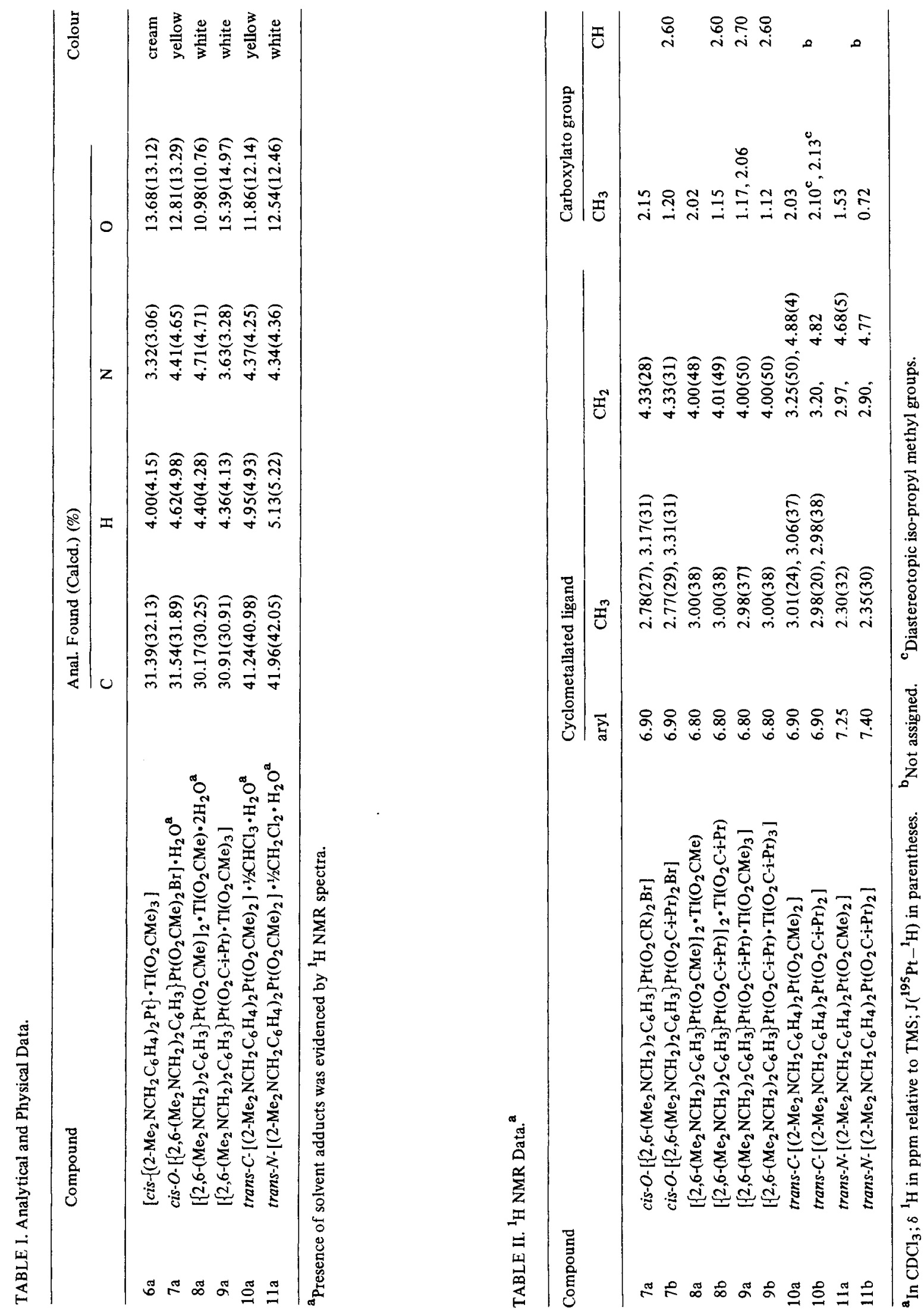
dino and triazenido complexes have been reported [7-9], whereas for thallium only $\mathrm{Ir}-\mathrm{Tl}$ bonded carboxylato compounds were isolated [10]. Analogous complexes of Rh could not be prepared; instead, a catalytic reduction of thallium(III) carboxylates to thallium(I) carboxylates was found [10]. It was furthermore shown that the potentially bidentate ligands have a large influence on the geometry and dynamic behaviour of the so formed heterodinuclear metal-mercury compounds.

In order to shed more light on the role of heterodinuclear metal complexes in electron and ligand transfer reactions and on the factors governing their formation and stability, we investigated the reactions of cyclometallated platinum(II) compounds with thallium(III) carboxylates.

In this paper we show that thallium carboxylates can be used to prepare otherwise intractable organoplatinum compounds, but do not lead to stable heterodinuclear complexes containing a Pt-Tl bond.

\section{Experimental}

Varian T-60, Bruker WP-80 and Perkin-Elmer 283 spectrometers were used for recording the ' $H$ and ${ }^{13} \mathrm{C}$ NMR and infrared spectra. Molecular weights were determined with a Hewlett-Packard vapour pressure osmometer, Model 320B. Elemental analyses were carried out at the Institute for Organic Chemistry TNO, Utrecht. Analytical data and characteristic IR absorptions are given in Table I, while ${ }^{1} \mathrm{H}$ and ${ }^{13} \mathrm{C}$ NMR data are presented in Table II and III, respectively.

The compounds cis- and trans- $\left[\left(2-\mathrm{Me}_{2} \mathrm{NCH}_{2} \mathrm{C}_{6}\right.\right.$ $\left.\mathrm{H}_{4}\right)_{2} \mathrm{Pt}$ ] [11] (1), (2), cis-[(2- $\left.\mathrm{Me}_{2} \mathrm{NC}_{6} \mathrm{H}_{4} \mathrm{CH}_{2}\right)_{2} \mathrm{Pt}$ ] [1b] (3), [\{2,6-( $\left.\left.\left.\mathrm{Me}_{2} \mathrm{NCH}_{2}\right)_{2} \mathrm{C}_{6} \mathrm{H}_{3}\right\} \mathrm{PtBr}\right]$ [12] (4), and $\left[\left\{2,6-\left(\mathrm{Me}_{2} \mathrm{NCH}_{2}\right)_{2} \mathrm{C}_{6} \mathrm{H}_{3}\right\} \mathrm{Pt}\left(\mathrm{O}_{2} \mathrm{CR}\right)\right]$ [13] (5) were prepared according to the literature.

Reaction of cis-[(2-Me $\left.\left.{ }_{2} \mathrm{NCH}_{2} \mathrm{C}_{6} \mathrm{H}_{4}\right)_{2} \mathrm{Pt}\right]$ with $\mathrm{Tl}$ $\left(\mathrm{O}_{2} \mathrm{CMe}\right)_{3}$

cis- $\left[\left(2-\mathrm{Me}_{2} \mathrm{NCH}_{2} \mathrm{C}_{6} \mathrm{H}_{4}\right)_{2} \mathrm{Pt}\right](0.233 \mathrm{~g}, 0.5 \mathrm{mmol})$ was dissolved in deuteriochloroform $(2.5 \mathrm{ml})$. $\mathrm{Tl}\left(\mathrm{O}_{2} \mathrm{CMe}\right)_{3}(0.191 \mathrm{~g}, 0.5 \mathrm{mmol})$ was added, which dissolved upon stirring. ${ }^{13} \mathrm{C}$ NMR spectra indicated that the starting Pt-compound had disappeared completely, while several new compounds were formed.

Filtration of the solution and evaporation of the solvent resulted in the isolation of a residue which analyzed fairly well for [(2- $\left.\mathrm{Me}_{2} \mathrm{NCH}_{2} \mathrm{C}_{6} \mathrm{H}_{4}\right)_{2} \mathrm{Pt}$ $\left.\mathrm{Tl}\left(\mathrm{O}_{2} \mathrm{CMe}\right)_{3}\right]$. Attempts to isolate some pure compounds, e.g. by slow diffusion of tetrahydrofuran or hexane into the chloroform solution, led to recovery of the starting Pt-compound. 
Reaction of cis-[(2-Me $\left.\left.{ }_{2} \mathrm{NC}_{6} \mathrm{H}_{4} \mathrm{CH}_{2}\right)_{2} \mathrm{Pt}\right]$ with $\mathrm{Tl}\left(\mathrm{O}_{2}-\right.$ $\mathrm{CMe})_{3}$

Addition of $\mathrm{Tl}\left(\mathrm{O}_{2} \mathrm{CMe}\right)_{3}(0.191 \mathrm{~g}, 0.5 \mathrm{mmol})$ to a solution of $c i s-\left[\left(2-\mathrm{Me}_{2} \mathrm{NC}_{6} \mathrm{H}_{4} \mathrm{CH}_{2}\right)_{2} \mathrm{Pt}\right](0.233$ $\mathrm{g}, 0.5 \mathrm{mmol})$ in deuteriochloroform $(2.5 \mathrm{ml})$ led to a variety of compounds, $\left({ }^{13} \mathrm{C} \mathrm{NMR}\right)$, probably as a result of decomposition reactions. All attempts to isolate pure, identifiable, compounds failed.

Reaction of $\left[\left\{2,6-\left(\mathrm{Me}_{2} \mathrm{NCH}_{2}\right)_{2} \mathrm{C}_{6} \mathrm{H}_{3}\right\} \mathrm{PtBr}\right]$ with $\mathrm{Tl}-$ $\left(\mathrm{O}_{2} \mathrm{CR}\right)_{3}(\mathrm{R}=\mathrm{Me}, \mathrm{i}-\mathrm{Pr})$

Addition of $\mathrm{Tl}\left(\mathrm{O}_{2} \mathrm{CR}\right)_{3}(0.5 \mathrm{mmol})$ to a stirred solution of $\left[\left[2,6-\left(\mathrm{Me}_{2} \mathrm{NCH}_{2}\right)_{2} \mathrm{C}_{6} \mathrm{H}_{3}\right\} \mathrm{PtBr}\right](0.233 \mathrm{~g}$, $0.5 \mathrm{mmol}$ ) in chloroform or toluene $(5 \mathrm{ml})$ resulted in a dark red solution. In a few seconds this colour disappeared and a yellow solution was obtained. A white precipitate was formed which was isolated by filtration. Identification by IR spectroscopy showed only the presence of carboxylato groups, and ${ }^{1} \mathrm{H}$ and ${ }^{13} \mathrm{C}$ NMR spectra of a freshly prepared solution in chloroform indicated the presence of two platinum compounds. The relative ratios were respectively $3: 2$ for $\mathrm{R}=\mathrm{Me}$ and $1: 2$ for $\mathrm{R}=\mathrm{i}$-Pr.

With $\mathrm{R}=\mathrm{Me}$ and toluene as the solvent, concentration by slow evaporation resulted in the precipitation of a yellow complex, which was identified as $\left[\left\{2,6-\left(\mathrm{Me}_{2} \mathrm{NCH}_{2}\right)_{2} \mathrm{C}_{6} \mathrm{H}_{3}\right\} \mathrm{Pl}\left(\mathrm{O}_{2} \mathrm{CMe}\right)_{2} \mathrm{Br}\right]$. The remaining solution still contained a mixture of two compounds but by repeated replenishment of the solvent and concentration by slow evaporation all $\left[\left\{2,6-\left(\mathrm{Me}_{2} \mathrm{NCH}_{2}\right)_{2} \mathrm{C}_{6} \mathrm{H}_{3}\right\} \mathrm{Pt}\left(\mathrm{O}_{2} \mathrm{CMe}\right)_{2} \mathrm{Br}\right]$ was filtered off allowing isolation of an almost pure amount of the other, more soluble complex as a white powder from the toluene solution. This product analysed as $\left[\left\{2,6-\left(\mathrm{Me}_{2} \mathrm{NCH}_{2}\right)_{2} \mathrm{C}_{6} \mathrm{H}_{3}\right\} \mathrm{Pt}\left(\mathrm{O}_{2}\right.\right.$ $\mathrm{CMe})]_{2} \mathrm{Tl}\left(\mathrm{O}_{2} \mathrm{CMe}\right) \cdot 2 \mathrm{H}_{2} \mathrm{O}$.

Reaction of $\left[\left\{2,6-\left(\mathrm{Me}_{2} \mathrm{NCH}_{2}\right)_{2} \mathrm{C}_{6} \mathrm{H}_{3}\right\} \mathrm{Pt}\left(\mathrm{O}_{2} \mathrm{CR}\right)\right]$ with $\mathrm{Tl}\left(\mathrm{O}_{2} \mathrm{CR}\right)_{3}(\mathrm{R}=\mathrm{Me}, \mathrm{i}-\mathrm{Pr})$

$\mathrm{Tl}\left(\mathrm{O}_{2} \mathrm{CR}\right)_{3}(0.2 \mathrm{mmol})$ was added to a solution of [\{2,6-( $\left.\left.\left(\mathrm{Me}_{2} \mathrm{NCH}_{2}\right)_{2} \mathrm{C}_{6} \mathrm{H}_{3}\right\} \mathrm{Pt}\left(\mathrm{O}_{2} \mathrm{CR}\right)\right](0.2 \mathrm{mmol})$ in $\mathrm{CH}_{2} \mathrm{Cl}_{2}(5 \mathrm{ml})$, stirred for 10 minutes and filtered off. The filtrate was evaporated to dryness and the resulting residue washed with pentane $(10 \mathrm{ml})$. Drying in vacuo yielded pure $\left[\left\{2,6-\left(\mathrm{Me}_{2} \mathrm{NCH}_{2}\right)_{2}\right.\right.$. $\left.\left.\mathrm{C}_{6} \mathrm{H}_{3}\right\} \mathrm{Pt}\left(\mathrm{O}_{2} \mathrm{CR}\right) \cdot \mathrm{T}\left(\mathrm{O}_{2} \mathrm{CR}\right)_{3}\right]$. Yield $90 \%$.

Reaction of trans- $\left[\left(2-\mathrm{Me}_{2} \mathrm{NCH}_{2} \mathrm{C}_{6} \mathrm{H}_{4}\right)_{2} \mathrm{Pt}\right]$ with T7$\left(\mathrm{O}_{2} \mathrm{CMe}\right)_{3}$

$\mathrm{Tl}\left(\mathrm{O}_{2} \mathrm{CMe}\right)_{3}(0.191 \mathrm{~g}, 0.5 \mathrm{mmol})$ was added to a stirred solution of trans-[(2- $\left.\left.\mathrm{Me}_{2} \mathrm{NCH}_{2} \mathrm{C}_{6} \mathrm{H}_{4}\right)_{2} \mathrm{Pt}\right]$ $(0.233 \mathrm{~g}, 0.5 \mathrm{mmol})$ in toluene or chloroform $(5 \mathrm{ml})$. The colour of the solution directly changed to yellow. After stirring for $10 \mathrm{~min}$ the remaining precipitate was filtered off and identified by infrared spectroscopy as $\mathrm{Tl}^{\mathrm{I}}\left(\mathrm{O}_{2} \mathrm{CMe}\right)$. Evaporation of the solvent resulted in isolation of [ $\left(2-\mathrm{Me}_{2} \mathrm{NCH}_{2} \mathrm{C}_{6} \mathrm{H}_{4}\right)_{2}$ $\left.\mathrm{Pt}\left(\mathrm{O}_{2} \mathrm{CMe}\right)_{2}\right]$ in almost quantitative yield. This was a mixture of two stereoisomers, which, as deduced from ${ }^{1} \mathrm{H}$ NMR experiments, were present in about 12:1 molar ratio (vide infra). Recrystallization from $\mathrm{CHCl}_{3} / \mathrm{THF}$ gave a pure amount of the main isomer as the $\mathrm{CHCl}_{3}$ adduct.

Reaction of $\left[\left(2-\mathrm{Me}_{2} \mathrm{NCH}_{2} \mathrm{C}_{6} \mathrm{H}_{4}\right)_{2} \mathrm{Pt}\left(\mathrm{O}_{2} \mathrm{CR}\right)_{2}\right](\mathrm{R}=$ $\mathrm{Me}, i-\mathrm{Pr})$

\section{With carboxylic acids}

$\mathrm{HO}_{2} \mathrm{CR}$ (1.5 equivalents) was added to a freshly prepared solution of the mixture of isomers of [(2$\left.\mathrm{Me}_{2} \mathrm{NCH}_{2} \mathrm{C}_{6} \mathrm{H}_{4}\right)_{2} \mathrm{Pt}\left(\mathrm{O}_{2} \mathrm{CR}\right)_{2}$ ] $(0.05 \mathrm{mmol})$ in $\mathrm{CDCl}_{3}$ $(0.3 \mathrm{ml})$, obtained from the reaction of trans-[(2$\left.\left.\mathrm{Me}_{2} \mathrm{NCH}_{2} \mathrm{C}_{6} \mathrm{H}_{4}\right)_{2} \mathrm{Pt}\right]$ with $\mathrm{Tl}\left(\mathrm{O}_{2} \mathrm{CR}\right)_{3}$ (see above). After several days ( 3 for $\mathrm{R}=\mathrm{Me} ; 10$ for $\mathrm{R}=\mathrm{i}-\mathrm{Pr}$ ) the initial ratio between the two isomers had completely inverted. Only some minor impurities were formed. Slow diffusion of hexane into the solution resulted in formation of a white precipitate of the initially minor isomer $\left[\left(2-\mathrm{Me}_{2} \mathrm{NCH}_{2} \mathrm{C}_{6} \mathrm{H}_{4}\right)_{2} \mathrm{Pt}\left(\mathrm{O}_{2}\right.\right.$ $\mathrm{CR})_{2}$ ]. Recrystallization from $\mathrm{CH}_{2} \mathrm{Cl}_{2} /$ hexane gave the solvent adduct.

\section{With methanol}

The reaction of $\left[\left(2-\mathrm{Me}_{2} \mathrm{NCH}_{2} \mathrm{C}_{6} \mathrm{H}_{4}\right)_{2} \mathrm{Pt}\left(\mathrm{O}_{2}\right.\right.$ $\mathrm{CMe})_{2}$ ] with $\mathrm{MeOH}$ was monitored with ${ }^{1} \mathrm{H}$ NMR spectrometry in a similar fashion as described above for $\mathrm{HO}_{2} \mathrm{CMe}$. In this case some intermediate products were formed after about 5 days, most probably methanol adducts, which mainly converted within two weeks in the initially minor isomer of [ $\left(2-\mathrm{Me}_{2}-\right.$ $\left.\left.\mathrm{NCH}_{2} \mathrm{C}_{6} \mathrm{H}_{4}\right)_{2} \mathrm{Pt}\left(\mathrm{O}_{2} \mathrm{CMe}\right)_{2}\right]$. Some minor impurities were also observed.

\section{Results}

Reactions of Cyclometallated Platinum Compounds with Thallium(III) Carboxylates

Reaction of the compounds cis-[(2- $\mathrm{Me}_{2} \mathrm{NCH}_{2} \mathrm{C}_{6}$ $\left.\left.\mathrm{H}_{4}\right)_{2} \mathrm{Pt}\right]$ (1) and cis-[(2- $\left.\left.\mathrm{Me}_{2} \mathrm{NC}_{6} \mathrm{H}_{4} \mathrm{CH}_{2}\right)_{2} \mathrm{Pt}\right]$ (3) with thallium(III) carboxylates $\mathrm{Tl}\left(\mathrm{O}_{2} \mathrm{CR}\right)_{3}$ in chloroform resulted in the dissolution of the thallium compounds and ${ }^{13} \mathrm{C}$ NMR spectra indicated that several new compounds had been formed. Evaporation of the solvent from the reaction of (1) with $\mathrm{Tl}\left(\mathrm{O}_{2}\right.$. $\mathrm{CMe})_{3}$ resulted in the isolation of products with overall stoichiometry $\left[\left(2 \cdot \mathrm{Me}_{2} \mathrm{NCH}_{2} \mathrm{C}_{6} \mathrm{H}_{4}\right) \mathrm{Pt} \cdot \mathrm{Tl}\left(\mathrm{O}_{2}\right.\right.$. $\mathrm{CMe})_{3}$ ] (6) according to elemental analyses (Table I). This product was studied by field desorption mass spectrometry, but no peaks for the molecular ion were observed (Table IV). The pattern with highest intensity, centered at 463 , corresponds to the cation of $\left[\left(2-\mathrm{Me}_{2} \mathrm{NCH}_{2} \mathrm{C}_{6} \mathrm{H}_{4}\right)_{2} \mathrm{Pt}\right]$. The pattern next in intensity, at 522 , corresponds to $\left[\left(2-\mathrm{Me}_{2} \mathrm{NCH}_{2} \mathrm{C}_{6}\right.\right.$ $\left.\left.\mathrm{H}_{4}\right)_{2} \mathrm{Pt}\left(\mathrm{O}_{2} \mathrm{CMe}\right)\right]^{+}$. Furthermore, patterns centred at mass 557 and 720 were observed. The latter value 
TABLE IV. Field Desorption Mass Spectroscopy Data.

\begin{tabular}{|c|c|c|c|c|c|}
\hline \multicolumn{2}{|c|}{ PtTl compound ${ }^{a}$} & \multicolumn{2}{|c|}{ PtHg compound ${ }^{\mathbf{b}}$} & \multicolumn{2}{|l|}{ Possible ions } \\
\hline $\mathrm{M} / \mathrm{Z}^{\mathrm{c}}$ & R.I. $^{d}$ & $\bar{M} / \mathrm{Z}^{\mathrm{c}}$ & R.I. $^{d}$ & Formula $^{e}$ & $M / Z$ (calcd) \\
\hline 463 & 1 & 463 & 1 & $(\mathrm{C}-\mathrm{N})_{2} \mathrm{Pt}$ & 463 \\
\hline 522 & 0.38 & 522 & 0.23 & $(\mathrm{C}-\mathrm{N})_{2} \mathrm{Pt}\left(\mathrm{O}_{2} \mathrm{CMe}\right)$ & 522 \\
\hline \multirow[t]{3}{*}{554} & 0.15 & 557 & 0.05 & & \\
\hline & & 583 & 0.04 & $(\mathrm{C}-\mathrm{N})_{2} \mathrm{Pt}\left(\mathrm{O}_{2} \mathrm{CMe}\right)_{2}$ & 581 \\
\hline & & 724 & 0.04 & $(\mathrm{C}-\mathrm{N})_{2} \mathrm{PtHg}\left(\mathrm{O}_{2} \mathrm{CMe}\right)$ & 723 \\
\hline \multirow[t]{2}{*}{720} & 0.12 & & & $(\mathrm{C}-\mathrm{N})_{2} \operatorname{PtTl}\left(\mathrm{O}_{2} \mathrm{CMe}\right)$ & 727 \\
\hline & & 783 & 0.22 & $(\mathrm{C}-\mathrm{N})_{2} \mathrm{PtHg}\left(\mathrm{O}_{2} \mathrm{CMe}\right)_{2}$ & 782 \\
\hline
\end{tabular}

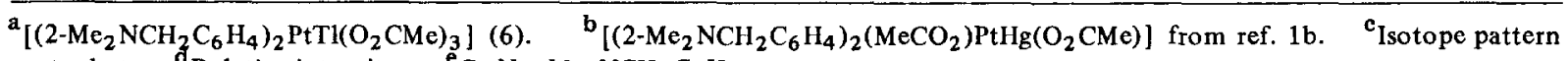
centred at. ${ }^{\mathrm{d}}$ Relative intensity. ${ }^{\mathrm{e}} \mathrm{C}-\mathrm{N}=\mathrm{Me}_{2} \mathrm{NCH}_{2} \mathrm{C}_{6} \mathrm{H}_{4}-$.

lies close to the mass of a particle $\left[\left(2-\mathrm{Me}_{2} \mathrm{NCH}_{2}\right.\right.$. $\left.\left.\mathrm{C}_{6} \mathrm{H}_{4}\right)_{2} \operatorname{PtTl}\left(\mathrm{O}_{2} \mathrm{CMe}\right)\right]^{+}$(727) and the isotope pattern was consistent with it. Attempts to isolate one of the products in pure form by slow diffusion. of a tetrahydrofuran or hexane layer into a chloroform solution led to the recovering of the cis-isomer (1). Likewise, all attempts to isolate a pure compound from the reaction of (3) failed.

Reaction of $\left[\left\{2,6-\left(\mathrm{Me}_{2} \mathrm{NCH}_{2}\right)_{2} \mathrm{C}_{6} \mathrm{H}_{3}\right\} \mathrm{PtBr}\right]$ (4) with thallium(III) carboxylates $\mathrm{Tl}\left(\mathrm{O}_{2} \mathrm{CR}\right)_{3}$ in $\mathrm{CH}_{2}$ $\mathrm{Cl}_{2}$ or $\mathrm{CHCl}_{3}$ immediately gave a white precipitate. From the IR spectra only the presence of carboxylato groups could be inferred. The presence of bromide atoms was indicated by the elemental analytical data for $\mathrm{R}=\mathrm{Me}$. The precipitate is thus likely to be a mixture of thallium(I) and thallium(III) carboxylates and bromides. From ${ }^{1} \mathrm{H}$ NMR the solution contained a mixture of two compounds, present in a ratio of $3: 2$ for $R=$ Me and $1: 2$ for $R=$ i-Pr. For $R=M e$, separation by fractional crystallisation yielded two pure compounds. The first, yellow, compound has the stoichiometry $\left[\left\{2,6-\left(\mathrm{Me}_{2} \mathrm{NCH}_{2}\right)_{2}\right.\right.$ $\left.\left.\mathrm{C}_{6} \mathrm{H}_{3}\right\} \mathrm{Pt}\left(\mathrm{O}_{2} \mathrm{CR}\right)_{2} \mathrm{Br}\right]$ (7) based on elemental analytical data. The second, white, compound gave elemental analytical data which are fairly close to a stoichiometry $\quad\left[\left\{2,6-\left(\mathrm{Me}_{2} \mathrm{NCH}_{2}\right)_{2} \mathrm{C}_{6} \mathrm{H}_{3}\right\} \mathrm{Pt}\left(\mathrm{O}_{2}\right.\right.$ $\mathrm{CMe})]_{2} \cdot \mathrm{Tl}\left(\mathrm{O}_{2} \mathrm{CMe}\right) \cdot 2 \mathrm{H}_{2} \mathrm{O}(8 \mathrm{a})$.

$\mathrm{Tl}\left(\mathrm{O}_{2} \mathrm{CMe}\right)_{3}$ dissolved in $\mathrm{CH}_{2} \mathrm{Cl}_{2}$ in the presence of $\left[\left\{2,6-\left(\mathrm{Me}_{2} \mathrm{NCH}_{2}\right)_{2} \mathrm{C}_{6} \mathrm{H}_{3}\right\} \mathrm{Pt}\left(\mathrm{O}_{2} \mathrm{CR}\right)\right] \quad(\mathrm{R}=\mathrm{Me}$, i-Pr) (5) up to a $1: 1$ molar ratio. From the solution a product (9) could be isolated which had $[\{2,6$ $\left.\left.\left(\mathrm{Me}_{2} \mathrm{NCH}_{2}\right)_{2} \mathrm{C}_{6} \mathrm{H}_{3}\right\} \mathrm{Pt}\left(\mathrm{O}_{2} \mathrm{CR}\right) \cdot \mathrm{Tl}\left(\mathrm{O}_{2} \mathrm{CMe}\right)_{3}\right]$ stoichiometry, as indicated by the elemental analyses for $\mathrm{R}=$ i-Pr.

Reaction of trans- $\left[\left(2-\mathrm{Me}_{2} \mathrm{NCH}_{2} \mathrm{C}_{6} \mathrm{H}_{4}\right)_{2} \mathrm{Pt}\right]$ (2) with thallium(III) carboxylates $\mathrm{Tl}\left(\mathrm{O}_{2} \mathrm{CR}\right)_{3}(\mathrm{R}=\mathrm{Me}$, i-Pr) immediately gave a precipitate, which was identified by $I R$ and elemental analytical data as $\mathrm{TI}^{\mathrm{T}}\left(\mathrm{O}_{2}\right.$. $\mathrm{Cr})$. The solution contained a mixture of two compounds $(\cong 12: 1$ ratio) which were identified by elemental analytical data and ${ }^{1} \mathrm{H}$ and ${ }^{13} \mathrm{C}$ NMR spectra as stereoisomers of $\left[\left(2-\mathrm{Me}_{2} \mathrm{NCH}_{2} \mathrm{C}_{6} \mathrm{H}_{4}\right)_{2}\right.$ $\left.\mathrm{Pt}\left(\mathrm{O}_{2} \mathrm{CR}\right)_{2}\right](10,11 ; \mathrm{a}, \mathrm{R}=\mathrm{Me} ; \mathrm{b}, \mathrm{R}=\mathrm{i} \cdot \mathrm{Pr})$.

\section{$\left[\left\{2,6-\left(\mathrm{Me}_{2} \mathrm{NCH}_{2}\right)_{2} \mathrm{C}_{6} \mathrm{H}_{3}\right\} \mathrm{Pt}\left(\mathrm{O}_{2} \mathrm{CR}\right)_{2} \mathrm{Br}\right]$ (7)}

For (7), a structure with a six-coordinate platinum atom is assigned. The meridional spanning of the $\{2,6$ $\left.\left(\mathrm{Me}_{2} \mathrm{NCH}_{2}\right)_{2} \mathrm{C}_{6} \mathrm{H}_{3}\right\}$ ligand with the rigid $\mathrm{Pt}-\mathrm{N}$ coordination is deduced from the $\mathrm{J}\left({ }^{195} \mathrm{Pt}-\mathrm{H}_{3} \mathrm{CN}\right)$ couplings. Cis-coordination of the carboxylato groups, resulting in a trans-coordination of the bromide atom and one carboxylato group, renders the $\mathrm{NMe}_{2}$ methyl groups diastereotopic, thus explaining the observation of two anisochronous $\mathrm{N}$-methyl resonances. In ref, $1 \mathrm{~b}$ a general outline about the characterization of these structures by dynamic NMR spectroscopy is given.

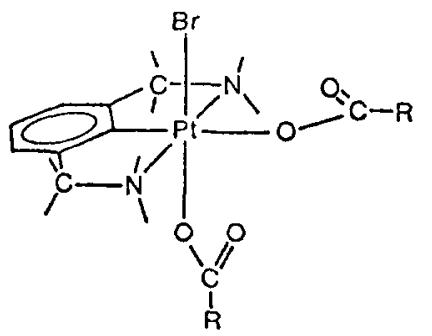

\section{$\left[\left\{2,6-\left(\mathrm{Me}_{2} \mathrm{NCH}_{2}\right)_{2} \mathrm{C}_{6} \mathrm{H}_{3}\right\} \mathrm{Pt}\left(\mathrm{O}_{2} \mathrm{CMe}\right)\right]_{2} \cdot \mathrm{Tl}\left(\mathrm{O}_{2} \mathrm{CMe}\right) \cdot$} $2 \mathrm{H}_{2} \mathrm{O}(8)$

The stoichiometry of (8) is supported by NMR spectra recorded after dissolution of the isolated product. The ${ }^{1} \mathrm{II}$ and ${ }^{13} \mathrm{C}$ NMR spectra point to enantiotopic $\mathrm{CH}_{2} \mathrm{H}$ atoms and $\mathrm{NMe}_{2}$ groups both with $\mathrm{J}\left({ }^{195} \mathrm{Pt}-{ }^{1} \mathrm{H}\right)$ couplings, indicating stable $\mathrm{Pt}-\mathrm{N}$ coordination. The complete ${ }^{1} \mathrm{H}$ and ${ }^{13} \mathrm{C}$ NMR patterns for the $\left\{2,6-\left(\mathrm{Me}_{2} \mathrm{NCH}_{2}\right)_{2} \mathrm{C}_{6} \mathrm{H}_{3}\right\}$ ligand closely resembled that of $\left[\left\{2,6-\left(\mathrm{Me}_{2} \mathrm{NCH}_{2}\right)_{2} \mathrm{C}_{6} \mathrm{H}_{3}\right\} \mathrm{PtBr}\right]$ [1b]. The compound is likely to be a platinum(II) com- 


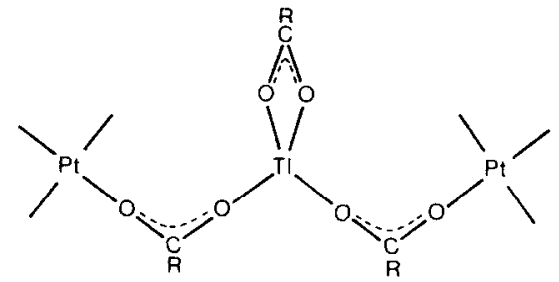

A

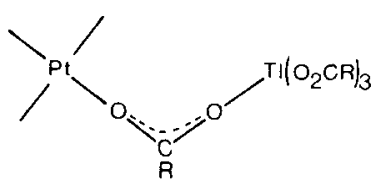

B

Fig. 1. Schematic structures of $\mathrm{Pt}-\mathrm{Tl}$ carboxylates 8 (A) and 9 (B). Pt-to-Tl donor interactions, if present, must be very weak and labile on the basis of the NMR data (see Discussion).

pound with a square planar structure. The fact that $\left[\left\{2,6-\left(\mathrm{Me}_{2} \mathrm{NCH}_{2}\right)_{2} \mathrm{C}_{6} \mathrm{H}_{3}\right\} \mathrm{Pt}\left(\mathrm{O}_{2} \mathrm{CMe}\right)\right]$ incorporates otherwise insoluble $\mathrm{Tl}^{1}\left(\mathrm{O}_{2} \mathrm{CMe}\right)$ is probably due to coordination via the platinum-bonded carboxylato groups. Thus a double bridged trinuclear structure seems to be present (see Fig. 1A).

\section{$\left[\left\{2,6-\left(\mathrm{Me}_{2} \mathrm{NCH}_{2}\right)_{2} \mathrm{C}_{6} \mathrm{H}_{3}\right\} \mathrm{Pt}\left(\mathrm{O}_{2} \mathrm{CR}\right) \cdot \mathrm{Tl}\left(\mathrm{O}_{2} \mathrm{CR}\right)_{3} /(9)\right.$}

The ${ }^{1} \mathrm{H}$ and ${ }^{13} \mathrm{C}$ NMR data of 9 , concerning the cyclometallated ligand are quite similar to those obtained for pure $\left[\left\{2,6-\left(\mathrm{Me}_{2} \mathrm{NCH}_{2}\right)_{2} \mathrm{C}_{6} \mathrm{H}_{3}\right\}\right.$ $\left.\mathrm{Pt}\left(\mathrm{O}_{2} \mathrm{CR}\right)\right]$ (5) [12]. Since the chemical shifts and particularly the coupling constants are rather sensitive to changes in the coordination geometry of the metal centre, we conclude that the coordination around platinum, going from compound 5 to 9 , has not been changed. Likewise, otherwise insoluble $\mathrm{Tl}\left(\mathrm{O}_{2} \mathrm{CMe}\right)_{3}$ must be present as an adduct, which may have been accomplished by coordination via the platinum bonded carboxylato group (see Fig. 1B).

A similar structure has been proposed for the reaction product of the reverse reaction between $\mathrm{Pd}\left(\mathrm{O}_{2} \mathrm{CR}\right)_{2}$ and $\left[\left\{2,6-\left(\mathrm{Me}_{2} \mathrm{NCH}_{2}\right)_{2} \mathrm{C}_{6} \mathrm{H}_{3}\right\} \mathrm{TlClBr}\right]$ [13].

$\left[\left(2-\mathrm{Me}_{2} \mathrm{NCH}_{2} \mathrm{C}_{6} \mathrm{H}_{4}\right)_{2} \mathrm{Pt}\left(\mathrm{O}_{2} \mathrm{CR}\right)_{2}\right](10,11)(a, \mathrm{R}=$ $M e ; b, R=i-P r)$

The ${ }^{1} \mathrm{H}$ and ${ }^{13} \mathrm{C}$ NMR spectra of each of the compounds 10 and 11 are compatible with equivalent $\mathrm{C}_{6} \mathrm{H}_{4} \mathrm{CH}_{2} \mathrm{NMe}_{2}$ ligands and equivalent coordinated carboxylato groups with ${ }^{3} \mathrm{~J}\left({ }^{195} \mathrm{Pt}-{ }^{13} \mathrm{C}\right)$ being observed for the $\alpha$-carbon atoms $(14 \mathrm{~Hz})$. Two diastereotopic $\mathrm{NMe}_{2}$ carbon atoms and an $\mathrm{AB}$ pattern for the $\mathrm{CH}_{2}$ hydrogen atoms are observed for both compounds. This indicates the absence of a plane of symmetry through the $\mathrm{C}$ and $\mathrm{N}$ centre in conjunction with a rigid coordination of the $\mathrm{NMe}_{2}$ groups to platinum. Two stereoisomeric structures, in which the acetato groups are in cis positions, and with either the
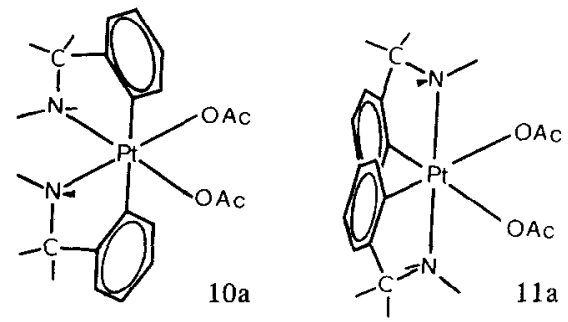

carbon or nitrogen atoms of the cyclometallated ligands in mutual trans positions, are consistent with the above facts.

The two compounds 10 and 11 differ very much with respect to their exhibited NMR chemical shifts. More or less normal chemical shifts are observed for the first stereoisomer, but for the second isomer 11 downfield shifts are observed for the aryl carbon atoms, and upfield shifts both for the hydrogen and carbon atoms of the $\mathrm{CH}_{2} \mathrm{NMe}_{2}$ moiety as well as for the acetato hydrogen atoms.

Interconversion of the Stereoisomers of /(2-Me $\left.\mathrm{NCH}_{2} \mathrm{C}_{6} \mathrm{H}_{4}\right)_{2} \mathrm{Pt}\left(\mathrm{O}_{2} \mathrm{CR}\right)_{2}$ ] (10), (11)

Addition of the corresponding free carboxylic acid to a freshly prepared solution of the mixture of the two compounds catalysed the conversion of the main isomer 10 into the second 11 . The conversion was complete in 3 days for 10 a with 2 equivalents of $\mathrm{HO}_{2} \mathrm{CMe}$ and in more then 10 days for $10 \mathrm{~b}$ with 2 equivalents of $\mathrm{HO}_{2} \mathrm{C}$-i.Pr. When 2 equivalents of $\mathrm{HO}_{2} \mathrm{C}-\mathrm{i}-\mathrm{Pr}$ were added to a solution of $10 \mathrm{a}$ in $\mathrm{CDCl}_{3}$, a mixture of $11 \mathrm{a}$ and $11 \mathrm{~b}$ was formed. A mixture of $11 \mathrm{a}$ and $\mathrm{HO}_{2} \mathrm{C}-\mathrm{i}-\mathrm{Pr}$ (2 equivalents in $\mathrm{CDCl}_{3}$ ) remained unchanged for several weeks.

Thus the conversion of 10 into 11 can occur with exchange between bonded carboxylato groups and free carboxylic acid, involving rupture of a $\mathrm{Pt}-\mathrm{O}$ bond, but such an exchange does not occur for the final product 11 .

Transformation of 10 into 11 was also possible with the addition of methanol. However, this reaction is much slower and involves new, relatively stable intermediate products, whose isolation has not been attempted.

It is generally found that bis-arylplatinum(II) compounds are more stable with the two aryl groups in cis-position compared with the transsituation [11]. The number of reported bis-arylplatinum(IV) is rather low, but those compounds will have a cis-geometry just like their methyl analogues [14]. On this basis the structure with trans- $C$-atonns is assigned to stereoisomer 10 and consequently stereoisomer 11 will have a structure with trans- $N$-atoms.

On the basis of the above results the following reaction scheme is proposed for the rearrangement, employing two different routes $\mathrm{A}$ and $\mathrm{B}$ (Scheme I). 


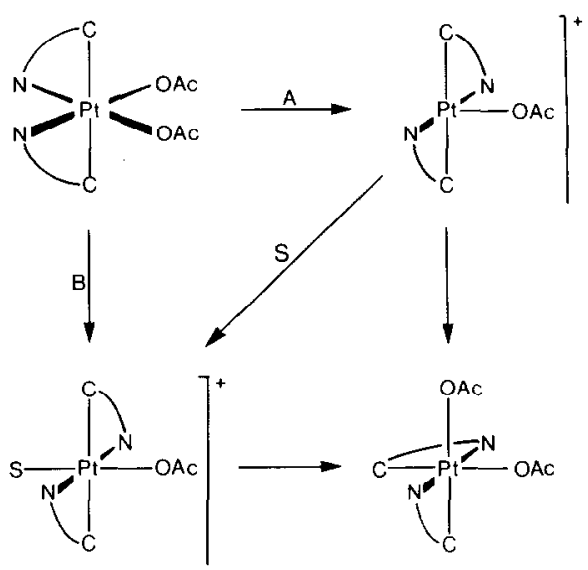

Scheme 1

The first step involves rupture of a Pt-O bond in 10 with simultaneous rearrangement of the cyclometallated ligands. There will thus be formed a fivecoordinate species (A), or a six-coordinate species by subsequent coordination of a free methanol or carboxylic acid molecule (B). A further rearrangement of the cyclometallated ligands, and eventual dissociation of the coordinated molecule (S) will take place followed by recoordination of a carboxylato group.

\section{Discussion}

In contrast to the previously reported organoplatinum-mercury compounds [1], containing either a covalent or donative $\mathrm{Pt}-\mathrm{Hg}$ bond, it has now been demonstrated that reactions of organoplatinum(II) compounds with thallium(III) carboxylates do not lead to similar stable heterodinuclear compounds containing a Pt-Tl bond.

The isolated product 6 from the reaction of $\mathrm{Tl}\left(\mathrm{O}_{2} \mathrm{CMe}\right)_{3}$ with 1 was studied by field desorption mass spectroscopy and showed an isotope pattern corresponding with the mass of $\left[\left(2-\mathrm{Me}_{2} \mathrm{NCH}_{2} \mathrm{C}_{6}\right.\right.$ $\left.\left.\mathrm{H}_{4}\right)_{2} \mathrm{PtTl}\left(\mathrm{O}_{2} \mathrm{CMe}\right)\right]^{+}$. Although 6 analyzed as [(2$\left.\left.\mathrm{Me}_{2} \mathrm{NCH}_{2} \mathrm{C}_{6} \mathrm{H}_{4}\right)_{2} \mathrm{PtTl}\left(\mathrm{O}_{2} \mathrm{CMe}\right)_{3}\right]$ no peaks were observed corresponding with the molecular ion of a platinum-thallium compound, and ${ }^{1} \mathrm{H}$ and ${ }^{13} \mathrm{C}$ NMR spectra indicated the presence of a mixture of compounds. In contrast, the corresponding platinum-mercury compound $\left[\left(2-\mathrm{Me}_{2} \mathrm{NCH}_{2} \mathrm{C}_{6} \mathrm{H}_{4}\right)_{2}\right.$ $\left.\left(\mathrm{MeCO}_{2}\right) \mathrm{PtHg}\left(\mathrm{O}_{2} \mathrm{CMe}\right)\right]$ of which the structure was solved by X-ray determination, showed peaks due to the molecular ion, along with similar degradation products [1b]. Furthermore, after work-up of the reaction mixture of 6 some starting products were isolated again.

Reaction of 2 with $\mathrm{Tl}\left(\mathrm{O}_{2} \mathrm{CR}\right)_{3}$ resulted in elimination of $\mathrm{Tl}^{\mathrm{I}}\left(\mathrm{O}_{2} \mathrm{CMe}\right)$ and formation of two stereoisomers of $\left[\left(2-\mathrm{Me}_{2} \mathrm{NCH}_{2} \mathrm{C}_{6} \mathrm{H}_{4}\right)_{2} \mathrm{Pt}\left(\mathrm{O}_{2} \mathrm{CR}\right)_{2}\right]$ (10),
(11), the latter in variable small amounts. These stereoisomers have been identified as trans-C- and trans- $\mathrm{N}-\left[\left(2-\mathrm{Me}_{2} \mathrm{NCH}_{2} \mathrm{C}_{6} \mathrm{H}_{4}\right)_{2} \mathrm{Pt}\left(\mathrm{O}_{2} \mathrm{CMe}\right)_{2}\right] . \quad$ The main isomer (10) was thermodynamically unstable and converted, under action of carboxylic acid, into the second stereoisomer (11). While generally it is found that cis-diorganoplatinum compounds are more stable than trans-diorganoplatinum compounds, the structure with the two carbon atoms in transposition was assigned to stereoisomer 10. 11 was consequently assigned a structure with trans $\mathrm{N}$ atoms.

Transformation of trans- $C$ - $\left[\left(2-\mathrm{Me}_{2} \mathrm{NCH}_{2} \mathrm{C}_{6} \mathrm{H}_{4}\right)_{2}\right.$ $\left.\mathrm{Pt}\left(\mathrm{O}_{2} \mathrm{CR}\right)_{2}\right]$ into trans- $\mathrm{N}-\left[\left(2-\mathrm{Me}_{2} \mathrm{NCH}_{2} \mathrm{C}_{6} \mathrm{H}_{4}\right)_{2}\right.$ $\left.\mathrm{Pt}\left(\mathrm{O}_{2} \mathrm{CR}\right)_{2}\right]$ inevitably involves rupture of a $\mathrm{Pt}-\mathrm{O}$ bond, and a reaction scheme with either a five-coordinate or a six-coordinate intermediate containing a coordinated carboxylic acid or methanol molecule is proposed. Interestingly, the destabilizing influence of trans-C-ligands has resulted in a greater lability of cis $\mathrm{Pt}-\mathrm{O}$ bonds, whereas in the stereoisomer with trans- $\mathrm{N}$-ligands no indication for $\mathrm{Pt}-\mathrm{O}$ bond rupture is observed.

In this respect it is noteworthy that intramolecular exchange of one monodentate and one chelating carboxylato group, as reported for $\left[\left(\mathrm{PPh}_{3}\right)_{2}(\mathrm{CO})\right.$. $\mathrm{Ru}\left(\mathrm{O}_{2} \mathrm{CR}\right)_{2}$ ] by Robinson et al. [15], proceeded via two mechanisms and that rupture of $\mathrm{Ru}-\mathrm{O}$ bonds was significantly influenced by the trans ligands $\mathrm{PPh}_{3}$ and $\mathrm{CO}$ respectively.

For $\left[\left\{2,6-\left(\mathrm{Me}_{2} \mathrm{NCH}_{2}\right)_{2} \mathrm{C}_{6} \mathrm{H}_{3}\right\} \mathrm{PtBr}\right]$ two competing reactions were observed, which involve elimination of $\mathrm{Tl}^{\mathrm{I}}\left(\mathrm{O}_{2} \mathrm{CR}\right)$ resulting in formation of the platinum(IV) species 7 and, very likely, exchange of a bromide atom and a carboxylato group between platinum and thallium, resulting in compound 8 . The structure of 8 is still uncertain and is proposed to contain bridging carboxylato groups between the $\mathrm{Pt}^{\mathrm{II}}$ and $\mathrm{Tl}^{\mathrm{I}}$ units as the main structural feature A similar structure, containing a bridging carboxylato group between a $\mathrm{Pt}^{\mathrm{II}}$ and a $\mathrm{Tl}{ }^{\mathrm{III}}$ unit, is proposed for 9 which is the only product from the reaction of $\left[\left\{2,6-\left(\mathrm{Me}_{2} \mathrm{NCH}_{2}\right)_{2} \mathrm{C}_{6} \mathrm{H}_{3}\right\} \mathrm{Pt}\left(\mathrm{O}_{2} \mathrm{CR}\right)\right]$ and $\mathrm{Tl}\left(\mathrm{O}_{2} \mathrm{CR}\right)_{3}$. In both 8 and $9 \mathrm{Pt}$-to-Tl donor bonding may be present. However, the NMR data reveal the presence of a molecular mirror plane containing the terdentate ligand. This requires that any $\mathrm{Pt}-\mathrm{Tl}$ interaction present be wcak.

A similar situation has been met for $\left[\left\{2,6-\left(\mathrm{Me}_{2}\right.\right.\right.$ $\left.\left.\left.\mathrm{NCH}_{2}\right)_{2} \mathrm{C}_{6} \mathrm{H}_{3}\right\}\left(\mathrm{RCO}_{2}\right) \mathrm{PtHgCl}_{2}\right]$ but in this case the presence of a $\mathrm{Pt}^{\mathrm{II}}$-to- $\mathrm{Hg}^{\mathrm{II}}$ donor bond was established by X-ray structure determination for analogous $\left[\left\{2,6-\left(\mathrm{Me}_{2} \mathrm{NCH}_{2}\right)_{2} \mathrm{C}_{6} \mathrm{H}_{3}\right\}\{p\right.$-tolylNC(H)N-i-Pr $\}$ $\mathrm{PtHgBrCl}]$ [13].

Both the formation of 8 and 9 can be envisaged to comprise adduct formation between platinum carboxylato and thallium carboxylato compounds. In the reactions of $\mathrm{Pd}\left(\mathrm{O}_{2} \mathrm{CR}\right)_{2}$ with $\mathrm{Tl}\left(\mathrm{O}_{2} \mathrm{CR}\right)_{3}$ 


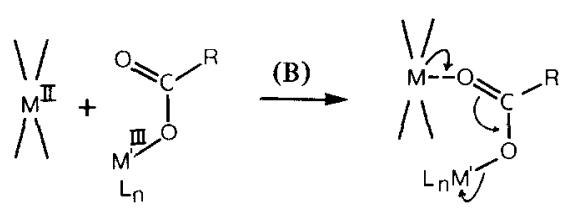<smiles>CCCC[Te]</smiles>

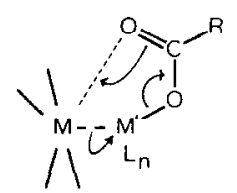
(A)

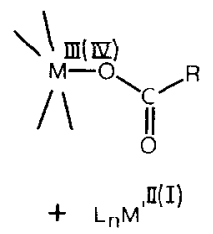

Scheme 2

we observed adduct formation by four $\mathrm{O}_{2} \mathrm{CR}$ groups bridging $P d$ and $\mathrm{Tl}$ [16]. Although in these adducts the $\mathrm{d}_{\mathrm{z}^{2}}$ orbital is suitably lined up for subsequent $\mathrm{Pd}-\mathrm{Tl}$ bond formation, such a reaction does not occur.

By contrast, the formation of the platinum(II) compounds 7,10 and 11 must have involved overall two-electron transfer reactions. For these two reactions two pathways can be considered (see Scheme II).

The first route (A) involves a sequence of steps analogous to those proposed for the reaction of cyclometallated platinum(II) compounds containing $\mathrm{N}$-donor ligands with mercury(II) carboxylates. The initial step would be nucleophilic attack of the $\mathrm{Pt}$ centre on the post-transition metal, leading to an intermediate with a Pt-to-post-transition metal donor bond ( $c f$. the isolation of unstable $\left[\left(2-\mathrm{Me}_{2}\right.\right.$ $\left.\mathrm{NCH}_{2} \mathrm{C}_{6} \mathrm{H}_{4}\right)_{2} \mathrm{PtHg}\left(\mathrm{O}_{2} \mathrm{CR}\right)_{2}$ ] [1]). In the case of mercury two further steps have been observed: i) one electron transfer leading to formation of a stable complex containing a covalent $\mathrm{Pt}-\mathrm{Hg}$ bond (cf. $\left[\left(2-\mathrm{Me}_{2} \mathrm{NCH}_{2} \mathrm{C}_{6} \mathrm{H}_{4}\right)_{2}\left(\mathrm{MeCO}_{2}\right) \mathrm{PtHg}\left(\mathrm{O}_{2} \mathrm{CMe}\right)\right]$

[1]) and ii) two electron transfer giving rise to platinum(IV) compounds [(2- $\left.\mathrm{Me}_{2} \mathrm{NCH}_{2} \mathrm{C}_{6} \mathrm{H}_{4}\right)_{2}$ $\left.\mathrm{Pt}\left(\mathrm{O}_{2} \mathrm{CR}\right)_{2}\right]$ and mercury $(0)$.

In the present work no stable $\mathrm{Pt} T \mathrm{Tl}$ bonded species were isolated, which indicates that if they are intermediates according to route $A$ they must be far less stable than the corresponding $\mathrm{Pt}-\mathrm{Hg}$ species. A low stability for a covalent $\mathrm{Pt}-\mathrm{Tl}$ bond would be remarkable in the light that for the metal-thallium compounds [ $\left.\left(\mathrm{PPh}_{3}\right)_{2}(\mathrm{CO}) \mathrm{X}\left(\mathrm{RCO}_{2}\right) \operatorname{IrT}\left(\mathrm{O}_{2} \mathrm{CR}\right)_{2}\right]$ (X $\left.=\mathrm{Cl}, \mathrm{O}_{2} \mathrm{CR}\right)$ a very stable $\mathrm{Ir} \mathrm{Tl}$ bond has been reported [10]. In fact, the only reported compound for which a $\mathrm{Pt}-\mathrm{T} l$ bond is proposed is $\left[\left(\mathrm{Ph}_{3} \mathrm{P}\right)_{2}\left(\mathrm{C}_{6} \mathrm{~F}_{5}\right)\right.$ $\mathrm{Br}_{2} \mathrm{PtTl}\left(\mathrm{C}_{6} \mathrm{~F}_{5}\right) \mathrm{Br}$ ] [7] ; however, its structure is uncertain.

An alternative for the electron-transfer process involving metal-metal bonded species might be an inner sphere electron-transfer process involving carboxylato bridged intermediates (see route $B$ in Scheme II). In such a process transfer of the carboxylato group(s) can be performed in the same step.

It is noteworthy that reaction of $\left[\left(\mathrm{Ph}_{3} \mathrm{P}\right)_{2}(\mathrm{CO})\right.$. $\mathrm{RhX}]\left(\mathrm{X}=\mathrm{Cl}, \mathrm{O}_{2} \mathrm{CMe}\right)$ with $\mathrm{Tl}\left(\mathrm{O}_{2} \mathrm{CMe}\right)_{3}$ resulted in catalytic reduction of the thallium compound and recovery of the rhodium complex, whereas the corresponding iridium complexes gave the above mentioned Ir-Tl bonded compounds [10]. By contrast, for both $\mathrm{Rh}$ and Ir very stable metalmercury bonded compounds are reported [7-9]. Very likely, the catalytic reduction with rhodium also involved carboxylato bridged intermediates, in which electron transfer occurred via the $\mathrm{CO}_{2}$ fragment resulting in alkyl radical generation.

Similar to what has been observed in the reactions of these cyclometallated $\mathrm{Pt}$ compounds with $\mathrm{Hg}\left(\mathrm{O}_{2}\right.$ $\mathrm{CR})_{2}[1 \mathrm{~b}]$, with $\mathrm{Tl}\left(\mathrm{O}_{2} \mathrm{CR}\right)_{3}$ also no transmetallation is observed.

\section{Conclusions}

Reactions of cyclometallated platinum compounds with $\mathrm{Tl}\left(\mathrm{O}_{2} \mathrm{CR}\right)_{3}$ do not result in stable $\mathrm{Pt}-\mathrm{Tl}$ bonded compounds but result either in adduct formation, electron transfer of ligand exchange. The reaction mechanism of the latter processes might involve bridging carboxylato groups without direct metalmetal honds.

\section{Acknowledgements}

We wish to thank Mr. R. H. Fokkens for recording the field desorption mass spectra. Investigations were supported in part by the Netherlands Foundation for Chemical Research (SON), with financial aid from the Netherlands Organisation for Pure Research (ZWO).

\section{References}

1 A. F. M. J. van der Ploeg, G. van Koten, K. Vrieze, A. L Spek and -A. J. M. Duisenberg, a) J. Chem. Soc., Chem. Commun., 469 (1980); b) Inorg. Chem., in press.

2 R. J. Puddephatt and P. J. Thompson, J. Chem. Soc. Dalton Trans., 1219 (1977);

J. K. Jawad and R. J. Puddephatt, J. Chem. Soc., Chem. Commun., 892 (1977).

3 J. K. Jawad and R. J. Puddephat,, Inorg. Chim. Acta, 31, L391 (1978). 
4 J. Kuyper, Inorg. Chem., 17, 1458 (1978).

5 J. Kuyper and K. Vrieze, Transition Met. Chem., 1, 208 (1976);

B. Steele and K. Vrieze, ibid., 2, 169 (1977).

6 P. I. van Vliet, personal communication.

7 P. I. van Vliet, J. Kuyper and K. Vrieze, J. Organomet. Chem., 122, 99 (1976).

8 P. I. van Vliet, G. van Koten and K. Vrieze, J. Organomet. Chem., 188, 301 (1980).

9 P. I. van Vliet, M. Kokkes, G. van Koten and K. Vrieze, Ibid., 187, 413 (1980).

10 P. I. van Vliet and K. Vrieze, J. Organomet. Chem., 139 , 337 (1977).

11 G. Longoni, P. Fantucci, P. Chini and F. Canziani, $J$.
Organomet. Chem., 39, 413 (1977).

12 G. van Koten, K. Timmer, J. G. Noltes and A. L. Spek, J. Chem. Soc., Chem. Commun., 250 (1978).

13 A. F. M. J. van der Ploeg, G. van Koten and K. Vrieze, J. Organomet. Chem., 222, 155 (1981); Inorg. Chem., (1982) in press.

14 T. G. Appleton, H. C. Clark and L. E. Manzer, J. Organomet. Chem., 65, 275 (1974).

15 C. J. Creswell, A. Dobson, D. S. Moore and S. D. Robinson, Inorg. Chem., 18, 2055 (1979).

16 A. F. M. J. van der Ploeg, G. van Koten and K. Vrieze, Inorg. Chim. Acta, 39, 253 (1980).

17 A. S. Nyholm, Quart. Rev., 24 (1970)1;

A. T. T. Hiek, Inorg. Chim. Acta, 14, 87 (1975). 